\title{
The Spaces of Finance in Iran and Turkey at the Beginning of the 20th Century: The Cases of Melli Bank, the Sepah Bank, Turkish Central Bank, and the Ziraat Bank
}

\author{
Farivash Ghanadi Maragheh* \& Hilal Tuğba Örmecioğlu**
}

\begin{abstract}
After the complex socio-political environment of the 19th century, modernist and nationalist movements began to rise significantly at the beginning of the following century. In Iran and Turkey, similar political and social circumstances caused these movements to operate boldly. Various reforms initiated by national-cum-modern governments led by comparable leaders in both countries, started new chapters in different fields in their countries; architecture was among them. Financial reforms were one of these which brought the need for new financial buildings to symbolize the national power and economical independence. Therefore, in both countries, the most famous architects of the period were chosen to design the new style of financial buildings which were going to be the important examples of the modern architectural style combined with the nationalist approach. This study aims to examine the architecture of the 20th-century financial structures in Iran and Turkey, to obtain information about the architectural ideologies affected by nationalism and modernization in both countries during this period. For this purpose, the case studies were selected among the significant financial buildings of the period such as Sepah Bank by Vartan Hovanessian, Melli Bank by Mohsen Foroughi, Turkish Central Bank by Clemens Holzmeister, and Ziraat Bank by Giulio Mongeri.
\end{abstract}

Keywords: Iran, Turkey, Modernization, Architecture, Financial Buildings.

M.A., Akdeniz University, Faculty of Architecture, Department of Architecture, Antalya, Turkey, farivashghanadim@gmail.com, ORCID: 0000-0002-7655-4929

** Assoc. Prof., Akdeniz University, Faculty of Architecture, Department of Architecture, Antalya, Turkey, ormecioglu@akdeniz.edu.tr, ORCID: 0000-0002-0662-4178 


\title{
20. Yüzyıl Başında İran ve Türkiye'deki Finansal Mekanlar: Melli Bankası- Sepah Bankası- Türkiye Merkez Bankası ve Ziraat Bankası Örnekleri
}

\author{
Farivash Ghanadi Maragheh* \& Hilal Tuğba Örmecioğlu**
}

$\ddot{O} \mathbf{z}$

19. yüzyıldaki karmaşık sosyo-politik ortamın ardından, modernist ve milliyetçi hareketler 20. yüzyılın başlarında dikkat çekici bir şekilde yükselmeye başlamıştır. Benzer siyasi ve sosyal koşullar bu hareketlerin İran ve Türkiye'yi de güçlü şekilde etkilemesine neden olmuştur. Her iki ülkede de benzer karakterdeki liderler tarafindan yönetilen modernist-ulusal hükümetlerce başlatılan çeşitli reformlar, aralarında mimarlığın da bulunduğu farklı alanlarda yeni açılımlar yaratmıştır. Ulusal gücü ve ekonomik bağımsızlığı simgeleyecek yeni yapılara olan ihtiyacı beraberinde getiren ekonomi alanındaki reformlar da bunlardan biridir. Bu nedenle, her iki ülkede de milli yaklaşımlarla birleştirilen modern mimari üslubun önemli örnekleri olacak olan finansal yapıların bu yeni mimari tarzını tasarlamak için dönemin en ünlü mimarları seçilmiştir. Bu çalışma, İran ve Türkiye'deki 20. yüzyıl finansal yapılarının mimarisini incelemeyi, bu dönemde her iki ülkede de milliyetçilik ve modernleşmeden etkilenen mimari ideolojiler hakkında bilgi edinmeyi amaçlamaktadır. Bu amaçla, dönemin önemli banka yapılarından olan Vartan Hovanessian tarafindan tasarlanan Sepah Bankaları, Mohsen Foroughi tarafindan tasarlanan Melli Bankaları, Clemens Holzmeister tarafindan tasarlanan Merkez Bankası Binası ve Giulio Mongeri tarafindan tasarlanan Ziraat Bankaları incelenmek üzere örnek olarak seçilmiştir.

Anahtar Kelimeler: Iran, Türkiye, Modernleşme, Mimarlık, Finansal Yapılar.

Yüksek Lisans Mezunu, Akdeniz Üniversitesi, Mimarlık Fakültesi, Mimarlık Bölümü, Antalya, Türkiye, farivashghanadim@gmail.com, ORCID: 0000-0002-7655-4929

** Doç. Dr., Akdeniz Üniversitesi, Mimarlık Fakültesi, Mimarlık Bölümü, Antalya, Türkiye, ormecioglu@akdeniz.edu.tr, ORCID: 0000-0002-0662-4178 


\section{Introduction}

The modernization movements, the first sparks of which started in European-centered Western countries, are therefore called "westernization" in non-Western countries such as Iran and Turkey. Although the history of modernism goes back to the $19^{\text {th }}$ century, the rise of the movement dates back to by the early 20th century -especially in the Eastern countries-. In addition to the progressive modernist transformations that took place in various fields such as art, literature, social life, and architecture, reactionary ideologies which are opposed to modernist movements also came to the fore in Europe and also the Middle East. Hence, it can be claimed that the modernization and nationalism movements have been processed concurrently in the 20th century. Although these two ideologies were fundamentally opposed, they were simultaneously influential in countries such as Iran and Turkey at the beginning of the 20th century.

Iran and Turkey are the two countries of the Middle East that have been frequently studied in comparison among many aspects such as political, historical, etc. due to the similarities and differences in the trajectories of modernity. These two countries have major similarities that invite researchers to compare different aspects. Both of these countries have strong imperial history and also have faced modernization processes under similar conditions. The new modernist and nationalist governments which were established by the reformist leaders in both of countries in close periods are one of the most important of these similarities between Iran and Turkey.

After the First World War, influential leaders such as Reza Pahlavi in Iran, Shah Amanullah Han in Afghanistan, and Mustafa Kemal Atatürk in Turkey interacted modernity and nationalism with their own laws. In other words, they tried to build new and modern societies by keeping their national values alive (Daneshvar Rouyandozagh, 2020, p. 291). For this reason, while on the one hand revolutions were made with great enthusiasm, on the other hand, national identity was tried to be preserved by sometimes inventing traditions (Elhan, 2019, p. 15) and sometimes placing traditional elements in the public environment in a symbolic way to have a continuum with the past. The regimes of Iran and Turkey were both changed at the beginning of the 20th century, the foundation of the Pahlavi dynasty by Reza Pahlavi in 1925 and the foundation of the Turkish Republic by 
Mustafa Kemal Atatürk in 1923 were one of the most important influences for modernization. Atatürk and Pahlavi both initiated revolutions in many fields such as politics, law, economy, social life, education, and culture. The meeting of the two leaders in 1934 and some of their decisions are the proof of their akin ideologies, common ideals, and goals.

The reformist leaders of these new nationalist-cum-modern governments in Iran and Turkey started to build a new and modern nation by making various reforms in social, cultural, educational, financial, etc. spheres. The architecture was one of the most consciously used tools to build the modern nation. Therefore, both of the governments tried to construct the modern nation by building new modernist-cum-nationalist style public buildings with all the means at their disposal. Hence, all kinds of public-service buildings such as educational, military, medical, administrative buildings, etc. have gained great importance in this period as they are used to reflect the national power of the new modern country. In fact, the state not only used every available economic means for the construction of these public buildings, but also invited experts and well-known architects from abroad. For instance, under the influence of politics of educational modernization, a need for new educational buildings suitable for western-style education occurred. Hence, in both countries, most of the significant educational buildings were designed not only in modernist style but at the same time by western architects.

Among these, bank headquarters and branches played a special role in representation of national ideologies both symbolically and ideologically, because they are the only non-governmental buildings that epitomize the national power and economical independence. For the new modern-cumnationalist architecture, most of which was represented by the construction of public buildings in the both countries, the architecture of financial buildings also meant the reflection of new ideologies in the private sector. Although both of the states played an important role in the establishment of the modern financial sector in this period, the autonomy of the financial sector was of great importance for a reliable and stable economy. Therefore, the architecture of financial institutions not only aim to reflect modern and nationalist approaches but also the autonomous corporate identity of the institution. As the financial buildings were loaded with complex representational challenges beyond their functional needs, the design of 
these buildings became a vital problem; hence prominent architects of the period were assigned to the design of bank buildings.

This paper aims to compare the architecture of the 20th-century financial structures in Iran and Turkey, to obtain information about the architectural ideologies affected by nationalism and modernization in both countries during this period. The main research question is whether the state-directed architectural a proach in the construction of public buildings in both countries was also adopted in the field of private sector. The scope of the study is limited with the financial buildings of the early 20th century in Iran and Turkey.

Although it is known that one of the founding partners of the financial sectors in this period was states, the scope of the study is limited to architecture of financial buildings. Because, the financial sector had been one of the few private sectors that has the economic capacity to build its own architectural style in Iran and Turkey at the beginning of the 20th century. Within the scope of the article, Sepah Banks designed by Vartan Hovanessian, Melli Banks by Mohsen Foroughi, Turkish Central Bank by Clemens Holzmeister and Ziraat Banks by Giulio Mongeri will be examined as case studies of representation of modern and national monetary politics.

\section{Methodology}

The article adopts a comparative methodology of the architecture of financial buildings in Iran and Turkey, which were built in the early years of the 20th century. In this method, the important bank buildings built by famous architects in both countries are being compared by their architectural style. The architectural style of these buildings is analyzed along with the architect's modernist and nationalist approaches applied in the architectural design of these financial buildings. The examination of these modern and national approaches includes the analysis of architectural features such as facades, ornaments, materials, plan schemes, geometric masses, etc. In addition to these architectural features, the architects of these financial buildings will also be introduced together with their modern-cum-national approaches within the scope of this paper.

In this article, in the continuation of the comparison of certain bank buildings in both countries, the common and different aspects of their 
architectural styles and modern-national approaches will be analyzed. Therefore, the financial buildings which were built under complex social, political, and financial circumstances in earlies of 20th century in both countries, will be compared to each other by their modern-cum-national architectural approaches. This comparison will be focused on the most obvious characteristics that represent a modern or a national perspective of the building.

In this article, it has been seen that the application of these characteristics differs not only between these two countries but also between various bank buildings constructed by different architects in the same country and in the same period. Therefore, this study aims to analyze various architectural approaches in both countries and their features reflected on financial buildings in the same period, to find their similarities and differences.

\section{The Modernization in the Financial Platforms in Iran and Turkey}

In the 20th century Iran was experiencing two notions concurrently: modernization and the building of new national power. The Pahlavi Dynasty, ruled by Reza Shah, was reforming country in several ways, one of which was finance. From the mid to late 1930s, famous magazines of the period such as The Official Newspaper, and Le Journal de The'ran published architectural images of newly built modern buildings such as modern banks, railway stations, hotels, sanatoriums, and bridges under titles such as "A Few Aspects of Modern Iran", "Iran has transformed itself into a modern country" (Grigor, 2005, p. 102). Among these buildings, bank offices were given a special attention as the representation of national capital and wealth.

Iran was highly economically reliant on foreign capital in the last years of the Qajar Dynasty before Reza Shah's reign. As Grigor (2005, p. 116) claims, one of the most radical reforms by the Pahlavi was the establishment of the first Iranian bank which was the proof of "freeing the state from foreign dependency in finance". Established in different cities of Iran during the reign of Reza Shah, Melli Banks had become one of the most important institutions in the field of finance under the goal of building modern and national sovereignty in Iran. 
Although the first attempts to establish the National State Bank of Iran known as the Melli Bank- were started during the Qajar period, they could not be accomplished due to the obstruction of foreign powers (Hamshahri Online, 2012, parag. 2). Established on a concession as the Imperial Bank of Persia in 1889, the British Bank of Middle East was functioned as the state bank of Iran -issuing banknotes, lending to the government, etc.- until the establishment of Bank Melli in 1927 (Pamuk, 1988, p. 359). After the Constitutional Revolution in 1906, the proposal of the Minister of Finance to solve the economic crisis by borrowing money from European countries was rejected in the National Assembly of Iran. As Farahani (2015) conveyed the "national sentiment was hurt by past loans and the behavior of foreign banks"; hence, members of the Parliament, who oppose foreign indebtment, called for the establishment of a National State Bank in order to cut off the political and economic oppression of foreign powers. However, the establishment of Melli Bank had been delayed due to political conflicts in Iran until the end of Qajar Dynasty (Archive.org, 2008).

\section{Figure 1}

\section{A drawing of Iran Melli Bank in 1928}

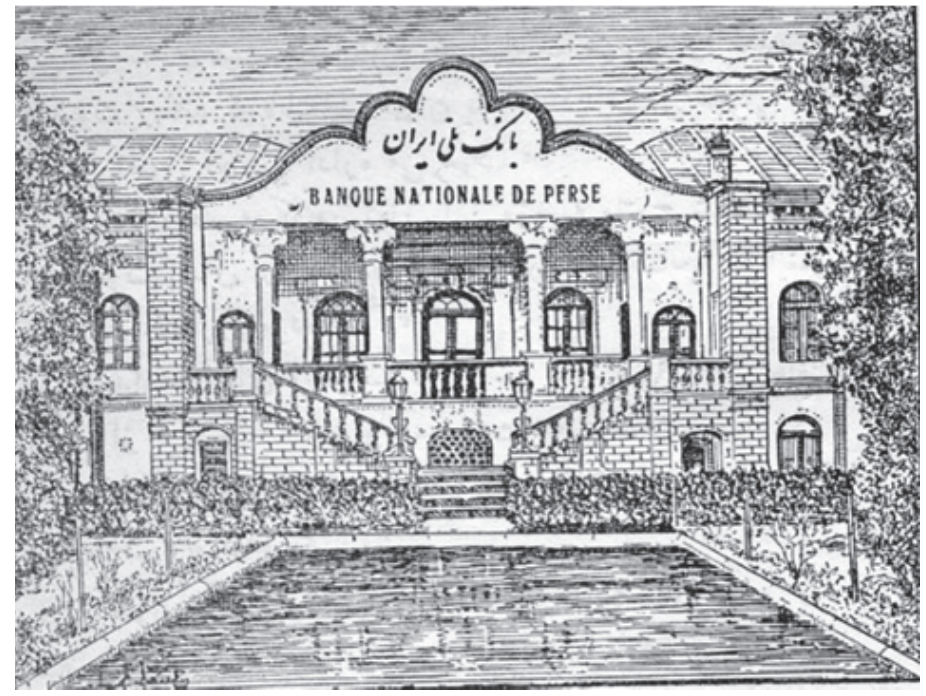

Note. From Bank-e Melli Iran naghashi dar 1307 [Drawing], by Wikipedia, 2008, (https://bit.ly/3qlogfi ). In the public domain. 
In Turkey, the financial issues of the country before Mustafa Kemal Ataturk were complicated as well. Ünay $(2010$, p. 110) described the late Ottoman financial situation as an "asymmetrical integration process with the European economy-politics". As interest is prohibited to Muslims, the non-Muslims have always been very influential in the Turkish financial sector; yet, foreign actors and non-Muslim wealthy families corner the market in the financial sector in the last years of the Ottoman Empire like in the Qajar Dynasty (İpek, 2011; Clay, 2000; Jones, 1986). In the Ottoman Empire these families came mainly from the Greek, Armenian and Jewish millets, and in Iran mainly from the Armenian and Zoroastrian (Parsee) communities. For prolonged periods from the 16th century to 19th century, in most parts of the Ottoman Empire and Iran, these families played a key role legally in the financial activities, along with the illegal practice of Muslim big merchant-entrepreneurs (tujja ${ }^{-}$) (Gilbar, 2012, p. 115).

The activities of foreign banks in Turkey had been initiated in the first half of the 19th century when Ottoman Empire accepted the Western finance and Western business model since the country hadn't enough amount of funds to build the national banking system. From the middle of the 18th century, until the establishment of new banks within the framework of the concessions, almost all of the banking activities in the Ottoman lands were carried out by Armenian, Greek and Jewish financiers known as "Galata Bankers" (Ünay, 2010, p. 121). In 1845, an organization similar to the foreign banks in Istanbul was established under the name of Istanbul Bank; however, it did not last long due to lack of funds and was closed in 1850. Although the first bank of Turkey, which was Ottoman Bank, had been established during the Ottoman Empire in 1855, it can't be claimed as a national bank since its headquarters were in London and two English entrepreneurs, Stephen Sleigh and Peter Pasquali, were running the bank (Arts and Culture, n.d.). The bank, which was reorganized under the name "Bank-1 Osmanî-i Şahane" in 1863, gained the privilege of printing banknotes for 30 years and gained the status of a state bank (Türkiye Cumhuriyeti Merkez Bankas1, 2018). The fact that the capital of this bank belongs to foreigners has led to reactions over time as in İran. In the $2^{\text {nd }}$ Constitutional Period, the idea of establishing a national central bank was initiated. For this purpose, the Ottoman İtibar-1 Milli Bankas1 was established on March 11, 1917, based on domestic capital; but could not be continued, due to the defeat of the Ottoman Empire in the First World War. 
It was the Ziraat Bank, founded in 1888 during the reign of Abdülhamit, the first national bank in Turkish history (Pıçak et al., 2018, p. 143).

The modernist revolutions that started right after Mustafa Kemal Atatürk's declaration of the Republic of Turkey were also reflected in the field of finance. Being aware of the need to establish a National State Bank, the early republican government provided for the formation of the Turkish Central Bank as an independent institution from the government. The Turkish Central Bank, which started its activities on October 3, 1931, was established as a joint stock company as an indication of its independence and difference from other public institutions. Following the Ziraat Bank, İş Bank, the first bank of the republican period, was established in 1924. Subsequently, bank branches began to be built in various cities of Turkey, primarily in the new capital: Ankara.

\section{Financial Buildings of Modernization Era in Iran and Turkey}

As mentioned before, in the earli e s of the 20th century, the new governments, reformist leaders, and the combination of modernization and nationalism triggered the rise in constructions. The construction of public buildings, especially financial buildings, continued rapidly in both countries during this period. Reza Pahlavi was a highly reformist leader who had the goal of making Iran a modern country with strong national power. Besides his ambitious reforms on several spheres such as social, cultural, educational, etc., he started a huge architectural revolution in Iran aiming at the representation of the modern and national ideals of the state. In line with this aim, architectural activities commissioned by Reza Shah concentrated on two areas: reconstruction of monumental structures and construction of new modern buildings.

Accordingly, the radical reforms of Reza Shah were highly reflected in architecture of the period. Most of the newly constructed buildings were public buildings that assum e $d$ to be the symbols of national power. Under these circumstances, where national capital was seen as national sovereignty, financial buildings also played an important role in representation. Although, the se reforms aimed at a financial freedom that was not dependent on Western powers, the financial buildings of the period, like the other buildings, were desired to have western typologies. 
For reaching this goal Reza Shah usually believed in Western educated experts. Grigor (2005) interpreted this as:

...Reza Shah's elite had felt that these Western experts were needed to give modern forms to new functions that had been historically absent in Iran suc $h$ as administrative offices, ministries, banks, prisons, dam s, bridges, barracks, schools, universities, museums, cinemas, cabarets, bars, villas, and parks modeled after their Western prototypes. While these architectural manifestations of modernity often served as tools to enhance and exercise state power, each succ e ssful building represented an important moment in Iran's architectural profession - each an emblem of new beginnings for the reformists. (p. 354)

It can be claimed that the ideology of Reza Shah became visible in the architecture of the financial institutions of the period. For instance, Mohsen Foroughi and Vartan Hovanessian who were the architects of Melli Banks and Sepah Banks were both educated in Western countries and had the modernist approach in their architectural style. The Melli Banks' first three buildings were built shortly after its establishment in 1927; one of them was in the downtown of Tehran, one in the Bazaar and the other in the state of Boushehr.

On the other hand, Turkey was not much different from Iran in terms of preferring architects who received professional training in foreign or western countries for such structures. In Iran the Sepah Banks and Melli Banks were designed by Vartan Hovanessian who was an Iranian architect that had his professional education in École Spéciale d'Architecture of Paris in France and Mohsen Foroughi who were graduated from École des Beaux-Arts of Paris in France as well. In Turkey the Ziraat Bank buildings and the İş Bank buildings were designed by Giulio Mongeri, an Ottoman architect, who was educated in Milan; while architect of the National State Bank of Turkey was Clemens Holzmeister, an Austrian architect graduated from Technische Universität Wien.

It is remarkable that the construction of financial buildings is given priority in the construction activities of both regimes in both Iran and Turkey. In the both countries, financial buildings, which are seen as the symbols of the national economy of the newly established modern country, were rapidly built in city centers, especially in the capitals. 


\subsection{The Sepah Banks by Vartan Hovanessian}

Architect Vartan is a famous architect of the 1950s who used the Art Deco style popular in Iran at the time, in his architectural works. He was one of the Western-educated architects of Iran who also had worked in Europe for a while. Vartan was graduated from École Spéciale d'Architecturel in the earlies of 20th century (1922). The École Spéciale d'Architecturel was a school of architecture which adopted a new educational philosophy opposite to Ecole des Beaux Art and initiated the notion of engineerarchitect instead of artist-architect (Hornstein-Rabinovitch, 1990). After his graduation, Vartan took part in many architectural projects in Paris and gained professional experience before returning to Iran. Vartan Hovanessian, who became one of the important architects of Iran by designing many buildings after returning home, can be interpreted as a modernist architect who tries to combine Iranian culture with modern style appropriately. Because as Hovanessian (1946, p. 90) stated, "a society should not be tied solely to its past; on the contrary, it should think more about the present and the future. Because everything in the world is under development; architecture is among them."

\section{Figure 2}

\section{Vartan Hovanessian}

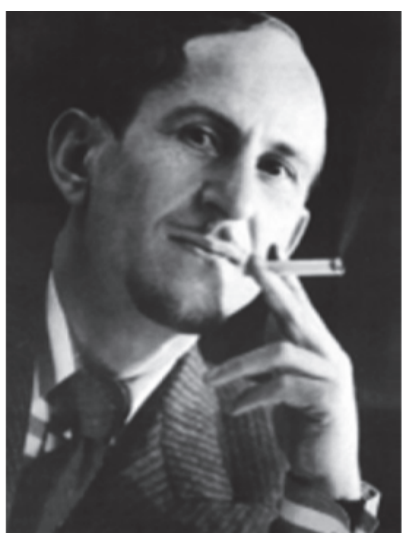

Note. From Vartan Hovanessian [Photograph], by Contemporary Architecture of Iran, 2021, (http://www.caoi.ir/en/projects/ item/636-vartan-hovanesian.html). Copyright 2012 by caoi.ir. In the public domain. 
During 1950s and 1960s most of the Sepah Bank branches had been designed by Vartan Hovanessian. The Sepah Bank's Tehran Branch (1950-1953), Esfehan Branch (1957-1959) and Central Branch (1964-1965) buildings are among Vartan's most important projects (Figure 3); and at the same time, are one of the important examples of the modernist-cum-nationalist architectural style among the financial buildings of the period. Vartan's bank buildings are classified as works of his third architectural period (Sorushiani et al, 2008). Therefore, it can be claimed that these bank buildings are the projects of Vartan's mastery period.

\section{Figure 3}

Left to right: The Sepah Bank Tehran Branch (1950-1953), Esfehan Branch (1957-1959) and The Central (Main) Branch (1964-1965)

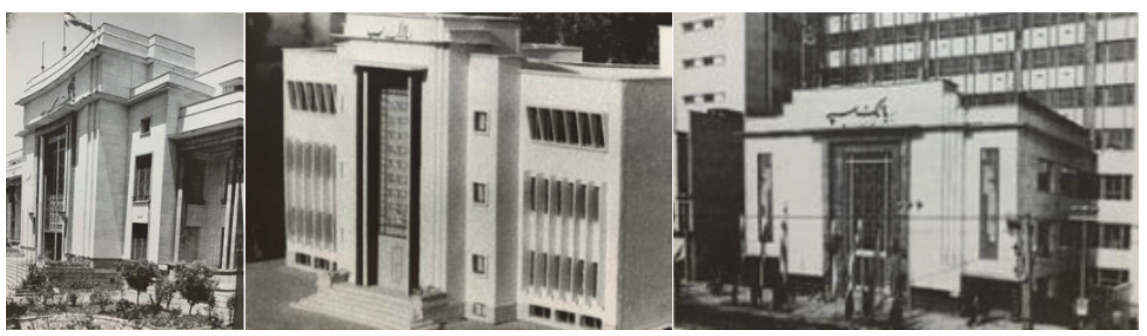

Note. From "Architecture of changing times in Iran: Vartan Hovanessian architecture" (p. 154-168), by S. Soroushiani, V. Daniel, and B. Shafei, 2008, Tehran: Iran: Did Publications.

The building of Sepah Bank Esfehan Branch was built in 1957. As it is in other Sepah Bank branches that had been designed by Vartan, the Art Deco style is combined with the characteristics of national architecture of Iran in Esfehan Branch (Sorushiani etc., 2008). In this building, the modernist character is provided by the cubic mass and basic modern decorations, while the nationalist character is implied by Iranian ornaments and especially the dome (Figure 4). Thus, the architect Vartan designed a financial building fitting with the nationalist and modernist spirit of the period. 


\section{Figure 4}

Left: The entrance of Esfahan Sepah Bank, right: The plan and section of Esfehan Sepah Bank

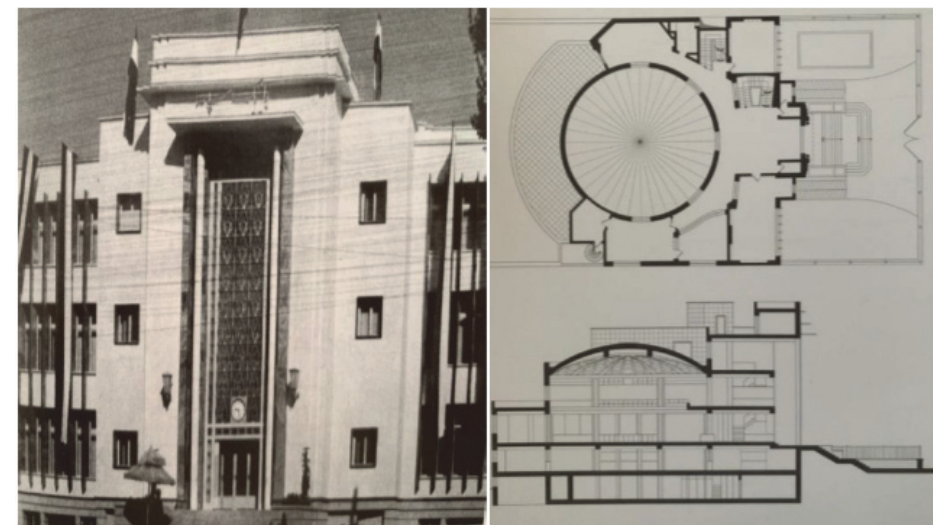

Note. From "Architecture of changing times in Iran: Vartan Hovanessian architecture" (p. 166-167), by S. Soroushiani, V. Daniel, and B. Shafei, 2008, Tehran: Iran: Did Publications.

\subsection{The Melli Banks by Mohsen Foroughi}

Although buildings of the Sepah Bank built in the 1950s and the 1960s are the significant representatives of the Iranian financial architecture in the 20th century, these building are not the first important examples of this architectural type. The Melli Banks, which date back to the Qajar Dynasty, has an older history in the field of financial corporations in Iran.

Mohsen Foroughi is the architect of the Melli Bank buildings in Iran during the 1940s. The buildings of Melli Bank Tabriz Branch (1940), Tehran Bazaar Branch (1941), Esfehan Branch (1941), and Shiraz Branch (Figure 6) were designed by Foroughi who was a popular name in architectural area in that period. As he was the son of Mohammad Ali Foroughi, the first prime minister of Reza Shah, he was personally close to the Pahlavi dynasty. Therefore, he truly adopted the opinions of Reza Shah, and placed an emphasis on Persian or Ancient nationalism in his architectural works. 


\section{Figure 5}

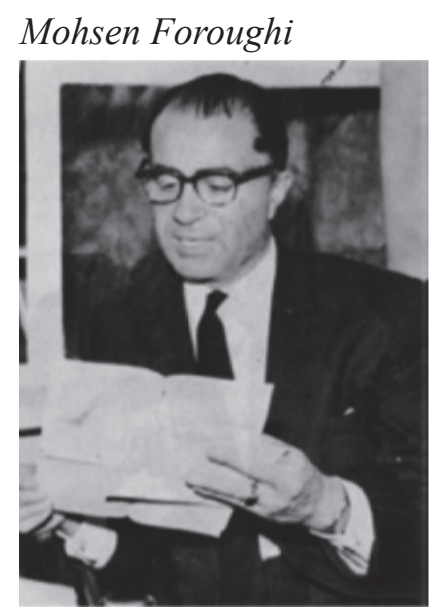

Note. From "Forugi Mohsen" by Encyclopedia Iranica by Frye and Marefat, 2012, (https://iranicaonline.org/articles/forugi-mohsen\#prettyPhoto [content]/0/) Copyright 2012 by Foroughi, P. In the public domain.

Not only Melli Banks, Foroughi had been the architect of many important national buildings during the First Pahlavi period. Intertwined with the new nation-state in Iran, he brought originality to its modernist structures with Pahlavi nationalism. Not surprisingly, he had his professional education in Europe as well; he was graduated from the École des Beaux-Arts in Paris in 1937 (Moghaddasi et al, 2020, p. 28). Foroughi was a modernist architect who admired Iranian cultural values and was one of the most important architects of the last years of Reza Shah's rule. As conveyed in Iran Architect Journal in 1948 "Mohsen Foroughi is considered one of our recognized and first-rate architects; With a full desire and enthusiasm, he rendered extraordinary services to the arch itectural changes of the country." (Architecthaye ma ra beshnasid: Mohsen Forough, 1948). 


\section{Figure 6}

Left to right: The Melli Bank building in Tabriz (1940) (Contemporary Architecture of Iran, 2019), The Melli Bank building in Esfehan (1941) and The Melli Bank in Shiraz

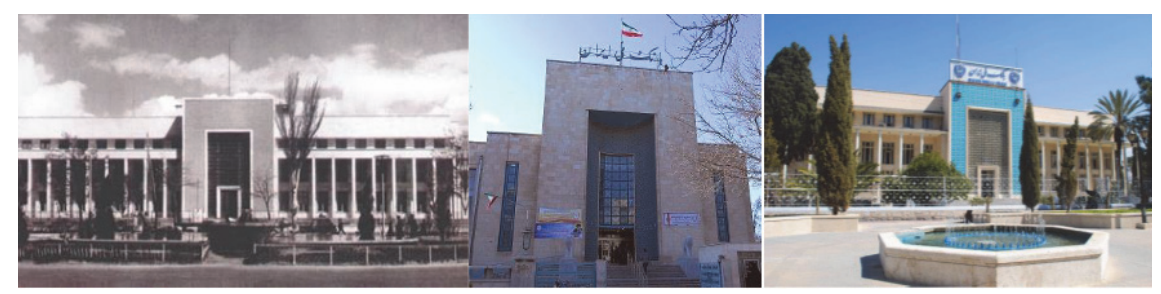

Note. Mohsen Foroughi designed the modern and national financial buildings, with his own architectural perspective, in The Melli Bank buildings. From "Melli Bank Tehran Bazzar Branch." by Contemporary Architecture of Iran, 2019, (http://caoi.ir/en/projects/item/375melli-bank-tehran-bazzar-branch.html) Copyright 2012 by caoi. ir. In the public domain. From "Bankhaye Khiaban-e Zand." by Payju, 2019, (http://caoi.ir/en/projects/item/375-melli-banktehran-bazzar-branch.html) Copyright 2019 by Shiraz New Courier Advertising Center. In the public domain.

As a graduate of École des Beaux-Arts, Foroughi frequently used symmetry in his plan schemes. Symmetry was also a principle in his plans for Melli Bank branches. Except for the Melli Bank building in Esfehan, Melli bank branches had a symmetrical plan schema (Figure 7). According to Akhgar (2018, p. 12), due to the site limitations, it was not possible for this building to have a symmetrical plan scheme like other projects. Moreover, in the Melli Bank buildings, Foroughi aimed for sustainability by paying close attention to climatic conditions. Therefore, he utilized some traditional climatic techniques. For instance, the material, which has been used in the fecade of Melli Banks, is a traditional material that has the ability of isolation; hence it can be claimed as a sustainable and vernacular material. 


\section{Figure 7}

Forughi 's plan structure and axes, A: asune Ecole des langues Orientales (school project), B: Faculty of Law, C: Melli Bank building in Esfehan, D: Melli Bank building in Shiraz, E: Melli Bank Tehran Bazar Branch, F: Melli Bank building in Tabriz

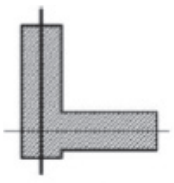

A

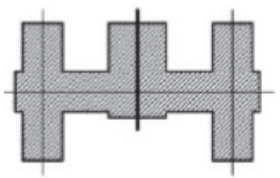

B
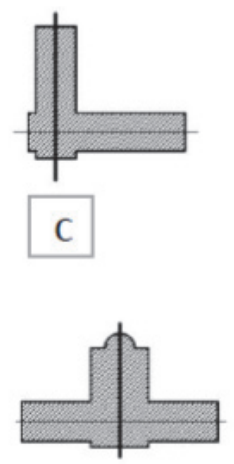

D
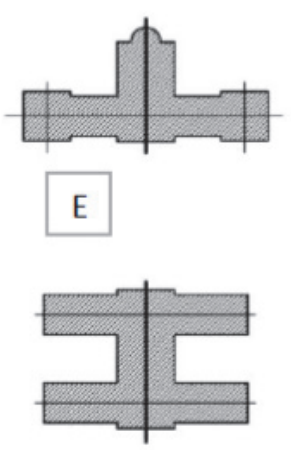

$\mathrm{F}$

Note. From "The ecole des beaux-arts and the advent of modern architecture in interwar Iran" by P. Akhgar, 2018, 35th annual conference of the society of architectural historians of Australia and New Zealand, 4(7), p. 12. Copyright 2018 by Society of Architectural Historians Australia and New Zealand. In the public domain.

Mohsen Foroughi interpreted the concepts of modernity and nationality in the Melli Bank buildings from his own architectural point of view. The reconciliation of modern and national architectural elements in the building of Esfehan Branch was achieved by combining modernist geometry with Iranian decoration styles. Mohsen Forughi applied his modernist approach with a simple geometry, using only concrete, stone and glass materials without intense ornaments. Although the building was surrounded by the historical buildings in Esfahan city, there was no similarity between this modern bank and other old buildings. On the other hand, the use of simple ornamentations of Iranian architecture such as Kashikari and the use of local spatial types such as iwan were some national elements applied in this building. However, the Kashikari and iwan had not 
been applied just for ideological and aesthetic concerns. The main idea of Mohsen Foroughi for using these national elements were their functional benefits. For example, Kashikari is useful for the isolation of cold and hot air; It was also the inspiration for the bank's logo (Akhgar, 2018, p. 12). Consequently, in the Esfehan branch of Melli Bank, Foroughi had caught the modernist part of his architecture by using modern materials, simple geometries and avoiding heavy ornamentations; using the Iranian and national architecture elements for their climate protection and decorations were the part that Mohsen Foroughi was applying his nationalist approach.

As a result, in the Esfehan branch of Melli Bank, Foroughi had captured the modernist side of his architecture by using modern materials, simple geometries and avoiding heavy ornaments, while applied the nationalist side by using traditional architectural elements for basic ornamentation and climatic protection.

\subsection{The Turkish Central Bank Building by Clemens Holzmeister}

Besides the national architects who had their professional educations in European countries, the foreign architects were also on the list of the most trustworthy architects to build the modern buildings of the new nation. Clemens Holzmeister was one of these foreign architects that played the significant role in forming the new capital city of Turkey, Ankara. The Austrian architect, who received his architectural education at the Technical School of Vienna, became one of the most trusted architects who built the most important structures of the early Republican Turkey, such as various ministry buildings and the Turkish Grand National Assembly. 


\section{Figure 8}

\section{Clemens Holzmeister}

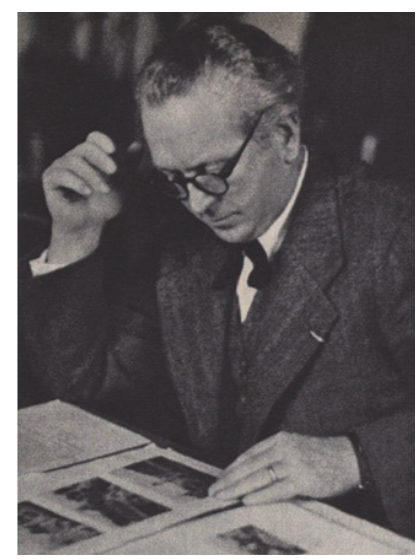

Note. From “Neugesstaltung des Festspielhauses" by Die Bühne, 1937, ANNO Historische Zeitungen und Zeitschriften, (451), p. 37. (https://anno. onb.ac.at/cgi-content/anno-plus?aid=bue \&datum $=1937 \&$ page $=84$ $7 \&$ size $=45$ ). Copyright 2011 by Österreichische Nationalbibliothek. In the public domain.

The architectural approach of Holzmeister is interpreted as a combination of monumental classicism and modernism, showing the "strength and determination of the new Turkish state" (Mimar Gözünden Ankara, 2016). According to Ballice and Karabağ Aydeniz (2016, p. 104), it is him who gave the first examples of the modernist architectural style that replaced the Ottoman Revival architectural style in Turkey after 1927. The courtyards, the $U$ formed plans and the use of symmetry was the most obvious characters of Holzmeister's architecture. Although, it has been claimed that the first architectural works of Holzmeister in Turkey had the universal style, after getting used to Turkish culture and Turkish architecture, his architectural approach started to get more vernacular. This transformation is more visible in his works after 1930 (Erkmen, 2003, p. 64).

The Turkish Central Bank building (1931- 1934), designed by Holzmeister is located next to The Ziraat Bank building in Ankara. In 1933 Emlak Bank was built in front of these buildings; therefore, by the middle of 1930s the avenue started to be known as the Banks' Avenue of Ankara (Ergut, 
2005, p. 29). Although this building was designed to be the headquarters of Emlak ve Eytam Bank, the building was transferred to the Turkish Central Bank due to the financial problems experienced during the construction process. The building is designed as spaces around the central hall, which is illuminated from the ceiling (Figure 9), and the working areas on the upper floor are placed around this atrium. The symmetrical mass design, the monumental entrance, natural stone covered façades and the windows of equal size giving a uniform effect on the façade are some of the characteristic features of Holzmeister architecture used in the design of the Turkish Central Bank. In order to balance this horizontally expanding mass, 2-storey high neo-classical columns of the entrance and vertical window arrangement on the façade were preferred (Koyuncu, 2010).

\section{Figure 9}

Left: The interior of Central Bank. Right: The entrance of Turkish Central Bank

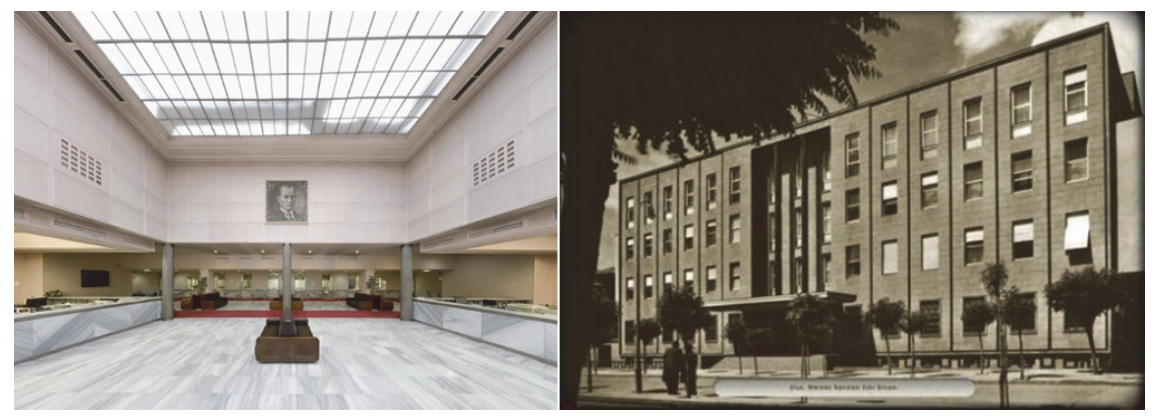

Note. From “Türkiye Cumhuriyeti Merkez Bankası” by Goethe-Institut, 2010 (https://www.goethe.de/ins/tr/ank/prj/urs/geb/ban/zen/trindex. $\mathrm{htm}$ ) Copyright 2020 by Goethe-Institut. In the public domain. From "Geçmişin modern mimarlığ1-8: Ankara-1" by P. Koyuncu, 2010, Arkitera, (https://v3.arkitera.com/h56097-gecmisin-modernmimarligi---8-ankara-1.html). Copyright 2021 by Arkitera Mimarlık Merkezi. In the public domain.

Besides these modernist features of Holzmeister architecture, there are national approaches in his architecture. Although Holzmeister tried to 
design a simple and modern façade, he also used some local materials, and traditional elements of the Turkish House. For example, although he avoided ornaments while designing cubical blocks with a modernist approach, he preferred to cover his cubic mass with a local material, called Ankara stone -a pinkish colored stone from Çubuk region-. This application was soon widespread and became a characteristic of early republican façades. In addition, Erkmen (2003, p. 61) spoke of Holzmeister architecture in Ankara as a climate-appropriate design, "interpreting traditional architectural forms as a contemporary regionalism".

\subsection{Ziraat Banks by Giluio Mongeri}

Just as Melli Bank is the oldest example of financial building architecture in Iran, Ziraat Bank's architecture, which has an older banking background, is one of the early examples of Turkish financial architecture after Ottoman Bank. As Saban (2019a, p. 495) stated, while Ottoman Bank buildings were inspired by the Renaissance palaces built in Europe, the national architectural style was adopted by Mongeri in Ziraat Bank buildings.

\section{Figure 10}

\section{Giulio Mongeri}

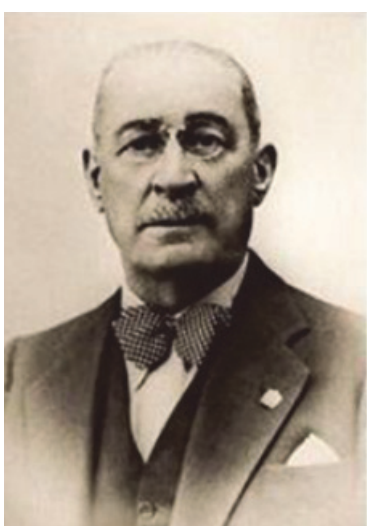

Note. From "Mimar Guilio Mongeri ve Majik sinemasi hakkında bir özet" by Starcephe, (n.d.), (http://www.starcephe.com/guilio_mongeri. $\mathrm{html})$. In the public domain. 
Giulio Mongeri was a popular architect of the late Ottoman period and a professor at Sanayi-i Nefise Mektebi during Vedat Tek's department chair. He taught many famous architects such as Sedad Hakk1 Eldem and Arif Hikmet Koyunoğlu. Mongeri is one of the architects of the period who was highly influenced by the First National Architecture Movement. In addition to his several buildings in Istanbul in the late Ottoman period such as St. Antuan Church (1912), Karaköy Palas (1920), Maçka Palas (1920), etc. he carried out important architectural works for Ankara, which was chosen as the new capital with the proclamation of the Republic (Çinici, 2015).

Along with his many other projects, he designed numerous financial buildings for different companies, such as Ziraat Bank, İş Bank and Ottoman Bank. These bank buildings can be claimed as his most precious architectural works. As Akşit (2010, p. 7) implies, the banks of the early Republican era were structuring economic independence and representing the national economy, and Mongeri embraced the I. National Architecture Movement in his buildings. The bank built in these years structures economic independence and represents national the economy." Furthermore, Giulio Mongeri had played a great role as a nationalist and modernist architect of that period in Turkey because he had affected intensely by The First National Architectural Movement. Thus, a successful financial architecture emerged from this harmonious alliance.

\section{Figure 11}

The Ziraat Bank Headquarters building in Ankara

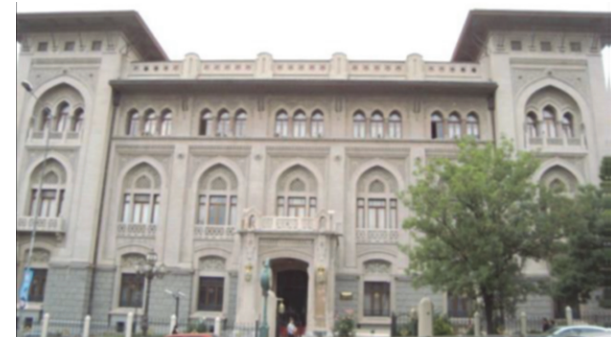

Note. From "Başkent Ankara’nın inşasında etkin bir mimar: Giulio Mongeri ve yaşam öyküsü” by D. Çinici, 2015, Ankara Araştırmaları Dergisi, 3(1), p. 26. (https://jag.journalagent.com/jas/pdfs/JAS_3_1_13_41.pdf). Copyri ght 2021 by Ankara Araştırmaları Dergisi. In the public domain. 
The Ziraat Bank Headquarters building, designed by Giulio Mongeri in 1929, is one of the significant examples of the First National Architecture Movement in Ankara which was rebuilt from scratch after the first decade proclamation of the republic. Nevertheless, in the first decade, the image of the capital was a continuation of the Ottoman reformist landscape, hence, the architectural character of this newly built environment was more nationalistic than modern. Şener $(2016$, p. 211) has interpreted this architectural character by these points: "Almost all of the ornaments and decoration elements used both inside the building and on the facade of the building contain traces of Seljuk and Ottoman art and architecture." (Figure 11).

Nevertheless, the Ziraat Bank building was not only as an important example of nationalist architecture. As mentioned before this building was one of the most important architectural construction in the new and modern capital city of a modern, national and reformist government. Therefore, it had the important role of symbolizing the new economic power, national sovereignty, independency, and modernism in architecture.

\section{Figure 12}

Left: The main hall of the Ziraat Bank in Ankara, right: the European style stained glass ornamentations of Ziraat Bank in Ankara

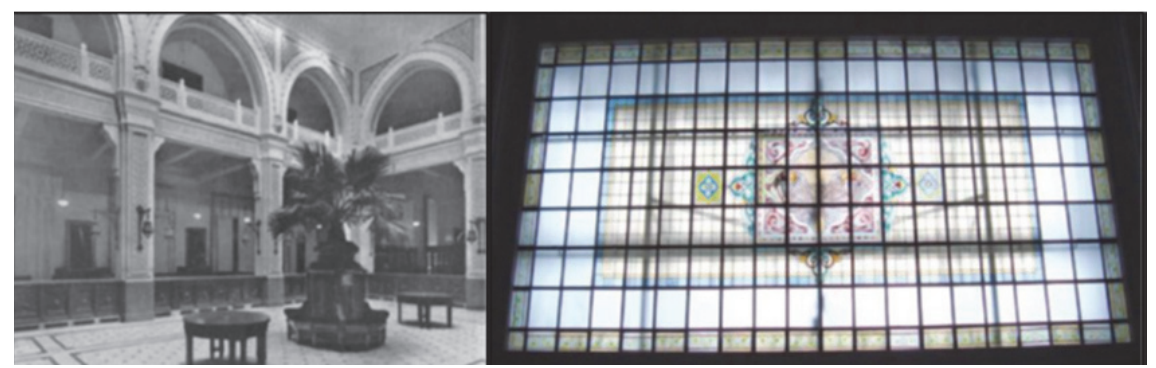

Note. From "Başkent Ankara'nın inşasında etkin bir mimar: Giulio Mongeri ve yaşam öyküsü" by P. Çinici, 2015, Ankara Araştırmaları Dergisi, 3(1), p. 28. (https://doi.org/10.5505/jas.2015.57966). Copyright 2021 by Ankara Araştırmaları Dergisi. In the public domain. 
In Ziraat Bank Headquarters, Mongeri who was also a licensee of the patented Hennebique system (Fasoli, 2017, p. 213), emphasized the modern aspect of the design by using the modern construction techniques and new materials such as reinforced concrete and steel. Despite the dominant use of Turkish motifs, European and Western motifs were also preferred in decoration, as well (Figure 12). On the other hand, the nationalist image of this bank was highly obvious. The facade and its decorations such as towers, pointed arches, tile embroideries, and floral patterns, and the symmetric plan schema with the central entrance were the elements of Ottoman Architecture.

However, Giulio Mongeri has been criticized because of his architectural preferences in this building, for instance, the excessive use of ornamentations. According to the statements of Zeki Sayar quoted by Tümer (1998, as cited in Şener, 2016), Atatürk, who wanted a modern architecture, did not like and approve of the style Ziraat Bank Headquarters building, which was designed in the style of the Ottoman revivalism, although it was a successful building. In other words, Giulio Mongeri was criticized for prioritizing aesthetics over modernist functionality (Hazar, 1986, as cited in Şener, 2016). Therefore, it has been a controversial issue how modern the Ziraat Bank Headquarters building can be interpreted, especially when compared with other buildings of the period, while being built with the newest techniques of its age, on the other hand, using the revitalization of historical styles. 


\section{Figure 13}

a) Ziraat Bank Building in İzmir, b) Ziraat Bank Building in Adana, c) Ziraat Bank Building in Aydın, d) Ziraat Bank Building in Eskişehir, e) Ziraat Bank Building in Kütahya, f) Ziraat Bank Building in Manisa.
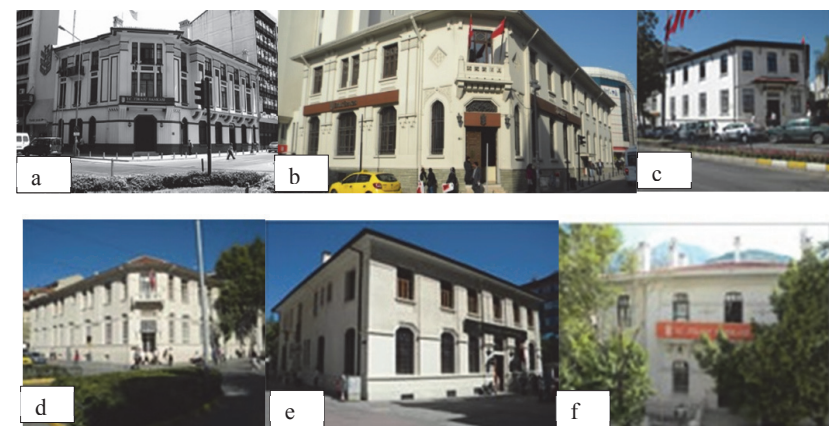

Note. From “Cumhuriyet dönemi mimarliği: Giulio Mongeri'nin Anadolu'daki izleri: Ziraat Bankası şube binaları” by D. Saban, 2019b, Mimarlık, (405), p. 73-74-75. (http://www.mimarlikdergisi.com/index.cfm? sayfa $=$ mimarlik\&DergiSayi $=419 \&$ RecID $=4626$ ). In the public domain.

Together with the Ziraat Bank Headquarters in Ankara, Mongeri also designed the branch buildings of the same bank in Izmir, Adana, Aydin, Eskisehir, Kutahya and Manisa between 1924 and 1930 (Figure 13). It is seen that Mongeri had achieved to develop modest but functional spatial organization in these Ziraat Bank branch buildings in five Anatolian cities, which were designed on parcels of different sizes and forms. Unlike the headquarters building in the capital, it is seen that the decorations on the facades of the branch buildings have decreased, and Ottoman motifs are also used in addition to geometric Art Deco motifs in the existing ones. As Saban (2019b) conveyed it can be argued that Ziraat Bank branch buildings have less ornamentation compared to its headquarters in Ankara, and functional needs are the determining factor in the design.

In addition, to being the architect of many branches of Ziraat Bank in several cities of Anatolia, Mongeri had also designed the buildings of two other important financial institutions, Ottoman bank and İş Bank, in Ankara, the capital of the new republic. 


\section{The Comparison of Financial Buildings in Iran and Turkey}

Iran and Turkey in the 20th century, experienced a great revolution in architecture along with many other fields such as social life, politics, finance etc. In this field, some special building types have started to attract more attention, so the interest in buildings with some special functions has increased. Finance was one of these functions. Hence the buildings of finance were designed by famous architects of their period and were considered as symbols in both countries. The popularity of modernist and nationalist movements and the modern-cum-national architectural styles together with the sociopolitical and socio-economical context of the period, caused the financial buildings to be the solid applications of the new architecture in Iran and Turkey.

As the modernist and nationalist contexts were similar in both countries, Iran and Turkey were similar in approach to architecture, in purpose and principle. However, despite similar modernist and nationalist goals, it had been applied from different perspectives due to cultural differences (Ghanadi Maragheh, 2021). Although different features can be seen in buildings designed by different architects in the same country, the main purpose of this article is to make a comparison between the two countries. Therefore, the analyzes of the comparison will be listed as similarities and differences between the financial buildings in Iran and Turkey.

The Ziraat Bank in Turkey and the Melli Banks in Iran were the first financial institutions established with national capital; therefore, the architecture of the buildings is also of special importance. Although, the Ziraat bank which visibly follows its Ottoman encounters of the 1st Nationalist Architecture Movement, elements such as domes were strongly avoided in the mass and façades of the Ziraat Bank. Instead, the building was inspired from elements of Anatolian domestic architecture such as fringed roof cover, cumba projections, etc. and these were all used in design on a modest scale. After all, as Bozdoğan (1996) conveys "the traditional "Turkish House" constitutes a recurrent theme in the 20th centuy Turkish architectural culture". On the other hand, the Melli Banks which represent the power of being the state bank of Iran was also inspired by traditional architecture and employed traditional elements such as iwan; but on a more visible scale. Nevertheless, after these first institutions, the financial sector started to rise rapidly in both countries; hence, various important bank buildings 
have been constructed such as Sepah Banks and Central Bank buildings in Iran.

In Iran, after a short time of building the Melli Banks (1940s) by Mohsen Foroughi the Sepah Banks (1950s) by Vartan Hovanessian started to be built. In Sepah Banks, the architect Vartan has combined the modern and national architecture as the modern materials and construction technics with the geometry of Iranian decoration. In Melli Banks by Mohsen Forughi, this combination was applied as the modern materials and technic with the functional and planimetric characteristics of Iranian architecture along with geometric decoration.

On the other hand, in Turkey, two architects of different architects, Mongeri and Holzmeister, who have different architectural styles, also dealt with the same dilemma: the reconciliation of modern and national elements in architecture. Giulio Mongeri who had been an important architect for designing the bank buildings since late Ottoman, had been the first choice for the design of financial buildings of the new Republic such as the Ziraat Banks and the İş Banks (1920s). Nevertheless, by the 1930's Clemens Holzmeister became an option due to his classist and modern style which suits with the desired image of modern and powerful state of the new Turkish Republic. The Turkish Central Bank by Holzmeister was designed as a cubic and modern mass of reinforced concrete frame with the addition of some vernacular architectural characteristics from the traditional Turkish architecture, such as the Ankara stone covered façades or climatic considerations. However, in the Ziraat Banks designed by Giulio Mongeri, the combination gets different. The use of modern building materials and construction technics were mutual, but Mongeri applies a completely Turkish style façade under the effect of The First National Architectural Movement.

As a result, it can be claimed that instead of an inclusive architectural understanding, in both countries, while the modernity of banks was represented by cubic masses, construction techniques and materials, it was expected to reflect national characteristics in architecture with decorations, façade layouts or sometimes small additions to their masses, such as the dome of the Sepah bank or the entrance of the Turkish Central Bank. Nevertheless, the number of decorative elements vary in different architects, for instance the use of ornamentations in Mongeri's Ziraat 
Banks were highly intense than other examples, since he was considered as a continuation of Ottoman Revivalism.

\section{Conclusion}

In the 20th century, modernization reached its highest level all over the world. Meanwhile, nationalist ideologies began to increase alongside modernist ideologies. One of the areas most affected by this dilemma had been the field of architecture, and nationalist architecture had risen as an opposition to cubic uniform buildings of modern architecture. This global situation began to affect Middle Eastern countries such as Iran and Turkey in a short span of time. Moreover, Iran and Turkey had special conditions that accelerated these transformations. The new governments established by leaders with common ideologies in both countries were the most effective among them. These conditions brought about epic reforms that caused a new wave in the field of architecture in both countries. One of the various reforms reflected in architecture was the financial reforms that gave impetus to the construction sector and thus to the construction of financial structures. These bank buildings were of great importance as they represented economic power, national independence, and the new modern country.

By establishing The Melli Banks in Iran and The Ziraat Banks in Turkey, the national financial institutions started their path in these modern nations. In the continuation, beside the branches of these institutions in capitals and various cities, the other bank brands started to build their buildings as well. Therefore, after Melli Banks by Mohsen Forughi and Ziraat Banks by Giulio Mongeri, The Sepah Banks by Vartan Hovanesian and The Turkish Central Bank by Clemens Holzmeister are some important examples of the financial buildings in that period. As it mentioned before, these buildings were designed by most famous architects of that time; who had the ability of symbolizing the national power and the modernity of these two new nations. Despite the fact that all these buildings are evaluated as the nationalism and modernist approach in architecture, the approaches of their architects have some differences. In the other words, it can be claimed that each of these architects in both countries emphasized their national and modern architecture differently by their own unique style. For instance, for architects such as Mohsen Foroughi the function and sustainability had its 
priority; but for Giulio Mongeri the decorations are being interpreted as the most distinct design approach. However, the modernist approach of architects was mostly mutual in these buildings; which were as using the modern materials, techniques and geometries.

As a result, it is possible to claim that in both countries, the famous architects of the financial buildings in 20th century, emphasized the natural power and economical independency of their country by their architecture in bank buildings. Although their national approaches of design had shown some differences, their modernist approaches were mostly mutual. It must be mentioned that despite the fact of the differences of their architectural approaches, the main goal of architects was also mutual; which was designing modern buildings by using national architecture characteristics. Therefore, these financial buildings in 20th century are important examples of different architectural styles in history of architecture in Iran and Turkey.

\section{Disclosure}

Both of the authors contributed equally to this article. The article is exempt from the Ethics Committee Decision. There are no participants. The author received no financial support from any institution and there's no conflict of interest. No material subject to copyright is included.

\section{Beyan}

Bu makaleye her iki yazar eşit katkı sağlamıştır. Bu makale etik kurul kararından muaftır. Çalışmada katılımcı bulunmamaktadır. Çalışma için herhangi bir kurum veya projeden mali destek alınmamıştır. Çalışmada kişiler ve kurumlar arası çıkar çatışması bulunmamaktadır. Telif hakkına sebep olacak bir materyal kullanılmamıştır. 


\section{References}

Akhgar, P. (2018, July, 4-7). The ecole des beaux-arts and the advent of modern architecture in interwar Iran. [Paper Presentation]. 35th annual conference of the society of architectural historians of Australia and New Zealand, Wellington, New Zealand. https://www. sahanz.net/wp-content/uploads/SAHANZ18_paper_Akhgar.pdf

Akşit, Ş. S. (2010). Ulusalcı mimarlık ve başkentte finans merkezi: Ankara İşB Bankası genel müdürlüğü (Publication No. 269171) [Master's thesis, Gazi University]. Thesis Center.

Architecthaye ma ra beshnasid: Mohsen Forough. (1948). Arkitekt, (6), 213-219.

Archive.org (2008, March 3). Tarikhcheye taasis-e Bank-e Melli Iran. https://web.archive.org/web/20180303110041/https://bmi.ir//Fa/ bmihistory.aspx? smnuid $=10$

Arts and Culture. (n.d.). Osmanlı Bankası Müzesi kuruluşu ve zor yıllar. https://artsandculture.google.com/exhibit/osmanli-bankasim\%C3\%BCzesi\%CC\%87-kurulu\%C5\%9F-ve-zor-yillar-salt/ QQnLUDFI?hl=tr

Ballice, G. \& Karabağ Aydeniz, N. E. (2016). The contribution of German architects to the Turkish architectural culture in the early republican period: an evaluation through Clemens Holzmeister. In P. Yildiz (Ed.), 1st international symposium 'education in interior architecture' in the year of German - Turkish research, education and innovation (pp. 104-116). Cambridge Scholars Publishing. https:// www.cambridgescholars.com/resources/pdfs/978-1-4438-8940-7sample.pdf

Bank-e Melli Iran naghashi dar 1307. (2008, November 7). In Wikipedia https://bit.ly/3ehC0oQ

Bozdoğan, S. (1996). Vernacular Architecture and Identity Politics: The Case of the "Turkish House.". Traditional Dwellings and Settlements Review, 7(2), 7-18. http://www.jstor.org/stable/41757194

Çinici, D. (2015). Başkent Ankara'nın inşasında etkin bir mimar: Giulio Mongeri ve yaşam öyküsü. Ankara Araştırmaları Dergisi, 3(1), 13-41 https://jag.journalagent.com/jas/pdfs/JAS_3_1_13_41.pdf 
Clay, C. G. A. (2000). Gold for the Sultan, western bankers and Ottoman finance, 1856-1881. I.B. Tauris.

Contemporary Architecture of Iran. (2019, October 19). Melli Bank Tehran Bazzar Branch. http://caoi.ir/en/projects/item/375-melli-banktehran-bazzar-branch.html

Contemporary Architecture of Iran. (2021, June 11). Vartan Hovanesian. http://www.caoi.ir/en/projects/item/636-vartan-hovanesian.html

Daneshvar Rouyandozagh, Y. (2020). Modernizm ve İran konutlarının dönüşümü (1870-1979). İran Çalışmaları Dergisi, 4(2), 283-314. https://doi:10.33201/iranian.821203

Die Bühne. (1937). Neugesstaltung des Festspielhauses, [ANNO Historische Zeitungen und Zeitschriften] 451. 38-40 https://anno.onb. ac.at/cgi-content/anno-plus?aid=bue \&datum $=1937 \&$ page $=847 \&$ si $\mathrm{ze}=45$

Elhan, N. (2019). Pehleviler dönemi'nde İran'da ulus-devlet: Milli kimlik ve geleneğin icadı. İan Çalışmaları Dergisi. 3(2), 13-37. https:// dergipark.org.tr/en/pub/iranian/article/630767

Ergut, E. A. (2005). Ankara 'Bankalar Caddesi' ve ötesi. In TMMOB Mimarlar Odası Bülten-Mimarlar Odası Ankara Şubesi. (31), 28-30. Matsa Publication. https://www.academia.edu/38338510/Ankara Bankalar_Caddesi_ve_\%C3\%96tesi

Erkmen, E. (2003). Clemens Holzmeister mimarlığı. Tasarım ve Kuram Dergisi, 2(3), 57-66. https://dergipark.org.tr/en/pub/tasarimkuram/ issue $/ 22537 / 240835$

Farahani, M. (2015, 23 August). Negahi be Bank-e Melli dar 87 salegi. http://naghdineh.com/page/9616

Fasoli, V. (2017). Giulio Mongeri Edoardo De Nari and the "Societâ Anonima Ottomana Costruzioni (S.A.O.C.). In P. Girardelli \& E. Godoli (Eds.), Italian architects and builders in the Ottoman Empire and modern Turkey: Design across borders (pp. 213-227). Cambridge Scholars Publishing.

Frye, R. N., \& Marefat, M. (2012). Forugi Mohsen. In Encyclopedia Iranica. Retrieved December 14, 2021, from https://iranicaonline.org/ articles/forugi-mohsen\#prettyPhoto[content]/0/ 
Ghanadi Maragheh, F. (2021). 20. yüzyıl başı Türkiye ve İran mimarisinde modern ve milli kavramlarinin incelenmesi (Publication No. 674986) [Master's thesis, Akdeniz University]. Thesis Center.

Gilbar G.G. (2012). The Qadi, the big merchant and forbidden Interest (ribā), British Journal of Middle Eastern Studies, 39(1), 115-136. https://doi.org/10.1080/13530194.2012.659441

Goethe-Institut. (2010). Türkiye Cumhuriyeti Merkez Bankası. https:// www.goethe.de/ins/tr/ank/prj/urs/geb/ban/zen/trindex.htm

Grigor, T. (2005). Cultivat(ing) modernities: The society for national heritage, political propaganda, and public architecture in twentiethcentury Iran (Publication No. 59671153) [Doctoral dissertation, Massachusetts Institute of Technology]. DSpace@MIT. https:// dspace.mit.edu/handle/1721.1/28748

Hamshahri Online. (2012, June 7). Ashnayi ba Bank-e Melli Iran. https:// www.hamshahrionline.ir/news/173264

Hornstein-Rabinovitch, S. (1990). Architecture on the edge: Stephen Sauvestre, the ecole centrale d'architecture, and marginalist practice. Journal of Architectural and Planning Research, 7(3), 209-221. https://www.jstor.org/stable/i40117231

Hovanessian, V. (1946). Masaele memari dar Iran. Arkitekt, (3). 90. İpek, N. (2011). Selanik ve İstanbul'da seçkin Yahudi bankerler (18501908) (Publication No. 287753) [Doctoral dissertation, Istanbul University]. Thesis Center.

Jones, G. (1986). Banking and empire in Iran: The history of the British bank of the middle east. Cambridge University Press.

Koyuncu, P. (2010, August 25). Geçmişin modern mimarlı̆̆ - 8: Ankara-1. Arkitera. https://v3.arkitera.com/h56097-gecmisin-modernmimarligi---8-ankara-1.html

Mimar Gözünden Ankara. (2016, May 1). Modern Ankara'yı taçlandıran mimarlar (1): Clemens Holzmeister. http://mimargozundenankara. weebly.com/ 
Moghaddasi, A., Moghaddasi, M., \& Khalilabad, H. (2020). Mohsen Foroughi (1907-1983): thoughts and sustainibility in the works of an Iranian modernist architect. Architecture and Engineering, 5(4), 2834. https://doi.org/10.23968/2500-0055-2020-5-4-28-34

Pamuk, S. (1988). Review: The history of the British bank of the middle east. by Geoffrey Jones. vol. 1: banking and empire in Iran. vol. 2: banking and oil. The Journal of Economic History, 48(4), 953-954. https://doi.org/10.1017/S0022050700006975

Payju. (2019, April 21). Bankhaye Khiaban-e Zand. https://bit. $1 y / 3 y S F J 5 v$

Pıçak, M., Süloğlu, D., \& Eker, A. (2018). Cumhuriyet'in ilk yıllarında Türkiye İş bankası'nın kuruluşu ve ekonomiye etkisi. In S. Koç, S. Y1lmaz Genç, \& K. Çolak (Eds.), Dünden Bugüne Ekonomi Yazıları (pp. 140-161). Kocaeli Üniversitesi Vakfi Yayınları. https:// www.academia.edu/34779807/D\%C3\%BCnden_Bug\%C3\%BCne_ Ekonomi_Yaz\%C4\%B1lar\%C4\%B1

Saban, D. (2019a). An architectural examination of early bank buildings in Turkey. Humanities and Social Sciences Review, 5(03), 493-503. http://www.universitypublications.net/hssr/0503/html/V6Z327.xml

Saban, D. (2019b). Cumhuriyet dönemi mimarliği: Giulio Mongeri'nin Anadolu'daki izleri: Ziraat bankası şube binaları. Mimarlık, (405), 73-77. http://www.mimarlikdergisi.com/index.cfm?sayfa=mimarlik\& DergiSayi $=419 \&$ RecID $=4626$

Şener, M. (2016). Cumhuriyet' in ilk yıllarında Ziraat Bankası ve İş Bankası hizmet binaları: 'milli mimarlık' ve banka yapıları. Tarih ve Uygarlı-Istanbul Journal, 1(9), 205-225. https://avesis.kocaeli.edu. tr/yayin/88395b8d-a50c-4866-a89c-2f7358f26d17/cumhuriyetinilk-yillarinda-ziraat-bankasi-ve-is-bankasi-hizmet-binalari-millimimarlik-ve-banka-yapilari

Soroushiani, S., Daniel, V., \& Shafei, B. (2008). Architecture of changing times in Iran: Vartan Hovanessian architecture. Did Publications.

Starcephe. (n.d.). Mimar Guilio Mongeri ve Majik sinemasi hakkında bir özet. http://www.starcephe.com/guilio_mongeri.html

Türkiye Cumhuriyeti Merkez Bankası. (2018). Türkiye cumhuriyet 
merkez bankası: Tarihçesi ve görevleri. https://www.tcmb.gov. tr/wps/wcm/connect/e6ccf55f-b2ac-4153-8d5a-c7ba61afa053/ TCMB+TK+BASKI+WEB.pdf?MOD=AJPERES

Ünay, S. (2010). Uluslararasi sistem ve iç dönüşüm: Osmanlıdan cumhuriyete Türkiye'nin kalkınma sorunsalı. Akademik Araştırmalar Dergisi, (45), 109-131. http://dspace.balikesir.edu.tr/xmlui/ handle/20.500.12462/4965 